\title{
地盤性状変化を考慮した海岸道路の 後浜斜面の高波による破壊メカニズムの解明
}

\author{
本間 大輔 1 - 宮武 誠 2 佐々 真志 $3 \cdot$ 木村 克俊 4 - 白水 元 $^{5} \cdot$ 蛯子 翼 6
}

\author{
1正会員 (国研)土木研究所 寒地土木研究所 寒地水圈研究グループ 寒冷沿岸域チーム \\ （广062-8602 札幌市豊平区平岸1条3丁目1-34） \\ E-mail:homma-d22aa@ceri.go.jp \\ 2正会員（独)函館工業高等専門学校准教授＼cjkstart社会基盤工学科（ T042-8501 函館市戸倉町14-1） \\ E-mail:miyatake@hakodate-ct.ac.jp \\ 3正会員 (国研)海上・港湾・航空技術研究所 港湾空港技術研究所 動土質研究グループ長 \\ （ ₹239-0826 横須賀市長瀬3-1-1） \\ E-mail:sassa@ipc.pari.go.jp \\ 4 フェロー会員＼cjkstart室蘭工業大学大学院教授 くらし環境領域（０050-8585 室蘭市水元町27-1） \\ E-mail:kimura@mmm.muroran-it.ac.jp \\ 5 正会員 熊本大学 自然科学研究科（干860-8555 熊本市中央区黒髪2丁目39-1) \\ E-mail:142 d9401@st.kumamoto-u.ac.jp \\ 6 正会員（独)函館工業高等専門学校＼cjkstart技術教育支援センター（率042-8501 函館市戸倉町14-1） \\ E-mail:t.ebiko@hakodate-ct.ac.jp
}

\begin{abstract}
オホーツク沿岸域における海岸道路の後浜斜面の被災状況を把握し, 現地踏査により得られた後浜斜面 の調査結果を踏まえ, 相対密度やサクション動態, ベーンせん断強度を様々に変化させた高波による盛土 の破壞実験を行った。その結果, 緩い不飽和斜面では高波によるサクション低下に伴うコラップス現象, 中〜密な不飽和斜面では高波による洗掘が確認され，相対密度及び飽和度の変化に伴う海岸道路幅員の欠 損パターンを明らかにし，高波による地盤性状変化に応じた海岸道路の破壊メカニズムを解明した。また， 後浜斜面の崩壊量は，相対密度と飽和度によって異なることを明らかにした。
\end{abstract}

Key Words : storm wave, saturation, suction, relative density, coastal road, damage pattern

\section{1. はじめに}

近年，日本周辺の北東アジアにおいて，発達速度が特 に大きい爆弾低気圧の発生頻度が増加しており，冬期に おける低気圧強度も増大傾向にあるとの報告もある11． 北海道オホーツク沿岸域においても，特に冬期の短期的 な波高増大がナウファスから確認されており，今後海岸 道路の後浜斜面に来襲する高波の頻度の増加が懸念され る. 後浜斜面の破壊は，高波により波浪が直接作用寸る ことにより進行するが，これとともに後浜斜面の地盤性 状は，不飽和から飽和状態に変化し，相対密度が低下し 飽和度が増加寸る. 後浜斜面が飽和状態になると土粒子 間に作用しているサクションによる粒子間付着力が消失 し，骨格岡性が低下寸ることによる体積圧縮减少（以後， コラップスと呼ぶ）が発生し，地盤強度の低下による破 壊が進行する．佐々ら (2) 3) 5) 5，地盤の飽和〜不飽和の 推移に対する地盤内に作用するサクションとの関係を明
らかとしているが，積雪寒冷地においては，降雨のみな らず春季における融雪の影響もあり，後浜斜面の地盤性 状は四季を通じて様々に変化し，季節によっては，相対 密度が低下し飽和度が増加するなど，より後浜斜面を破 壊させや寸い状況となる。

本研究では，高波により後浜斜面の破壊が生じたオ小 ーツク海沿岸域での海岸道路の後浜斜面の被災状況を把 握し，現地踏査により得られた後浜斜面の地盤強度試験， 相対密度試験結果を踏まえ，相対密度やサクション動態， ベーンせん断強度を様々に変化させた高波による盛土の 破壞実験を行った。これにより，高波作用下の地盤内に おける物理状態の変化に伴う地盤性状変化による後浜斜 面の破壊メカニズムを解明することを目的と寸る。

\section{2. オホーツク海沿岸における高波による後浜斜 面の被災概要と現地走査}


近年，オホーツク海沿岸域において高波による海岸道 路の後浜斜面の被害が発生している. 被害事例1（写真1(a)）は，国道238号線のA地区において，10年確率波相 当の高波（沖波波高 $H_{0}=7.5 \mathrm{~m}$ ，有義周期 $T=10.5 \mathrm{~s}$ ） が作用 した時の後浜斜面の被害状況である. 汀線から道路盛土 斜面までの海底勾配は1:10程度で，距離は60m程度であ った. 被災当時, 道路面のD.L+7.9mまで波が遡上し，後 浜斜面が部分的に被災していた．被害事例2（写真-1(b)） は，同じ路線のB地区において，30年確率波相当の波浪 （沖波波高 $H_{0}=8.0 \mathrm{~m} ）$ が作用した時の後浜斜面の被害状 況である. 汀線から道路盛土斜面までの勾配は1:8, 距 離は25m程度であった．被害範囲は100mの広範囲に及び， 後浜斜面が全て消失し, 路肩舗装部分が久落するまで破 壊が進行した. 上記被害状況から，後浜斜面の地盤性状 の調查が可能な被害事例1のA地区を対象に現地走査を 行った.

図-1は調査の対象としたA地区の代表断面地形である。 後浜斜面は汀線から約60mの位置にあり，主に砂粒子で 構成され，0.2mm〜2.0mmの比較的狭い範囲に集中し， 中央粒径 $d_{50}=1.2 \mathrm{~mm}$ 付近の粗砂が 8 割に及ぶ. 調查概要を 表-1に示寸．図-2は，2015年3月25日，10月6日に実施し た相対密度試験結果である. 測定地点 $\mathrm{A} \sim \mathrm{C}$ は, 後浜斜 面中腹部，測定地点Dは砂浜で計測した結果である. 両 日とも調查期間前後において晴天であり，降雨の影響は 小さい条件であったが，3月期の相対密度は10月期と比 較して大きく異なり 30〜50\%程度低下している．図-3は， 地盤表層のベーンせん断試験によるせん断強度の変化で ある. 測定点No.1 No.2は後浜斜面，No.3は後浜斜面法 先，No.4〜7は砂浜で測定した結果であり，3月，10月と もに前浜から後浜斜面に向かってせん断強度は増加する が，融雪期となる3月では，10月と比較して全体的に5割 の強度の低下がみられる。

観測したデータは少なく, 潮位や気象などの日変動の 影響までは明確ではないが，相対密度試験およびせん断 強度試験の結果から, 積雪が融解する3月期では, 地盤 内の飽和度が増加することにより，地盤が緩詰めとなっ たことが起因し，後浜斜面全域の相対密度が低下したと 考えられる.このように寒冷地の海岸道路では，季節変 動による地盤性状変化が大きいことが確認された.

\section{3. 実験方法}

\section{(1) 固定床不規則波実験による被災波浪の再現}

はじめに，後浜斜面に被害をもたらした被害事例1の 波浪を再現するため, 固定床による水理模型実験を行っ た. 反射吸収式造波装置を備えた2次元造波水路（長さ $24 \mathrm{~m}$, 幅 $0.8 \mathrm{~m}$, 深さ $1.0 \mathrm{~m})$ に, 現地の地形に合わせて沖 岸方向に1:30から1:10勾配のモルタル製固定床を設置し,

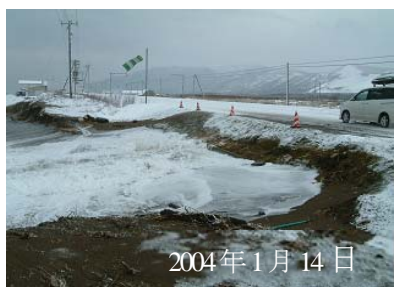

(a) 被害事例 1 (A 地区)

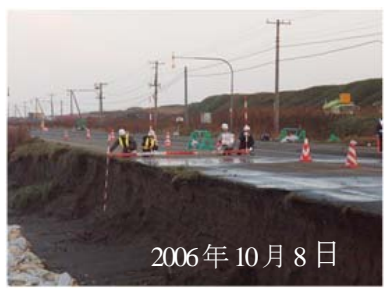

(b) 被害事例 2 (B地区)
写真-1 オホーツク海沿岸の後浜斜面の被災状況

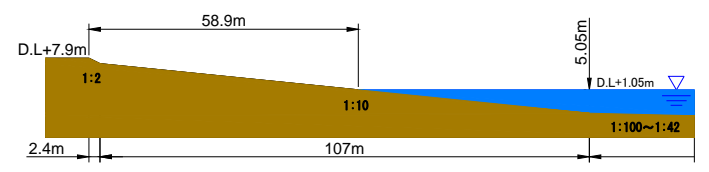

図-1 A 地区の断面地形

表-1 現地調査概要

\begin{tabular}{c|c}
\hline 調査項目 & 調査月日 \\
\hline 底質粒度試験 & $2015 / 3 / 25,2015 / 10 / 6$ \\
相対密度試験 & $2015 / 3 / 25,2015 / 10 / 6$ \\
せん断強度試験 & $2015 / 3 / 25,2015 / 10 / 6,2016 / 3 / 29$ \\
\hline
\end{tabular}

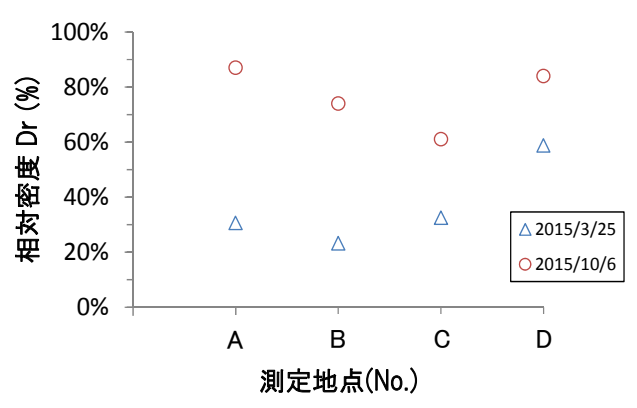

図-2 相対密度の変化

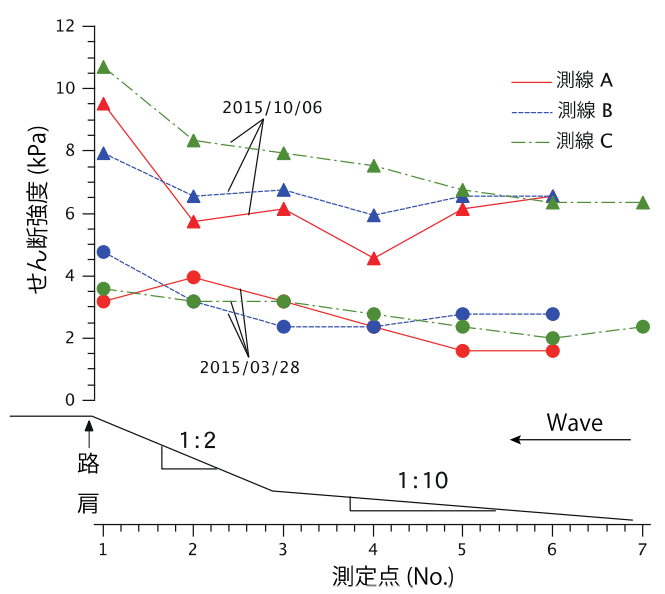

図-3 せん断強度の変化

模型縮尺は1/45とした．実験には不規則波を用い，1波 群を200波とし，被災相当波浪である $H_{0}=7.5 \mathrm{~m} ， T=10.5 \mathrm{~s}$, 潮位D.L.+1.05mをべースに2周期，5波高に変化させた. 波の遡上の計測には，1:10勾配部分に溝を設置し，容量 線を水路床と同じ高さに設定し，遡上高Rを計測した. また，併せて遡上流速 $u$ を遡上高 1 周期あたりのエネル 


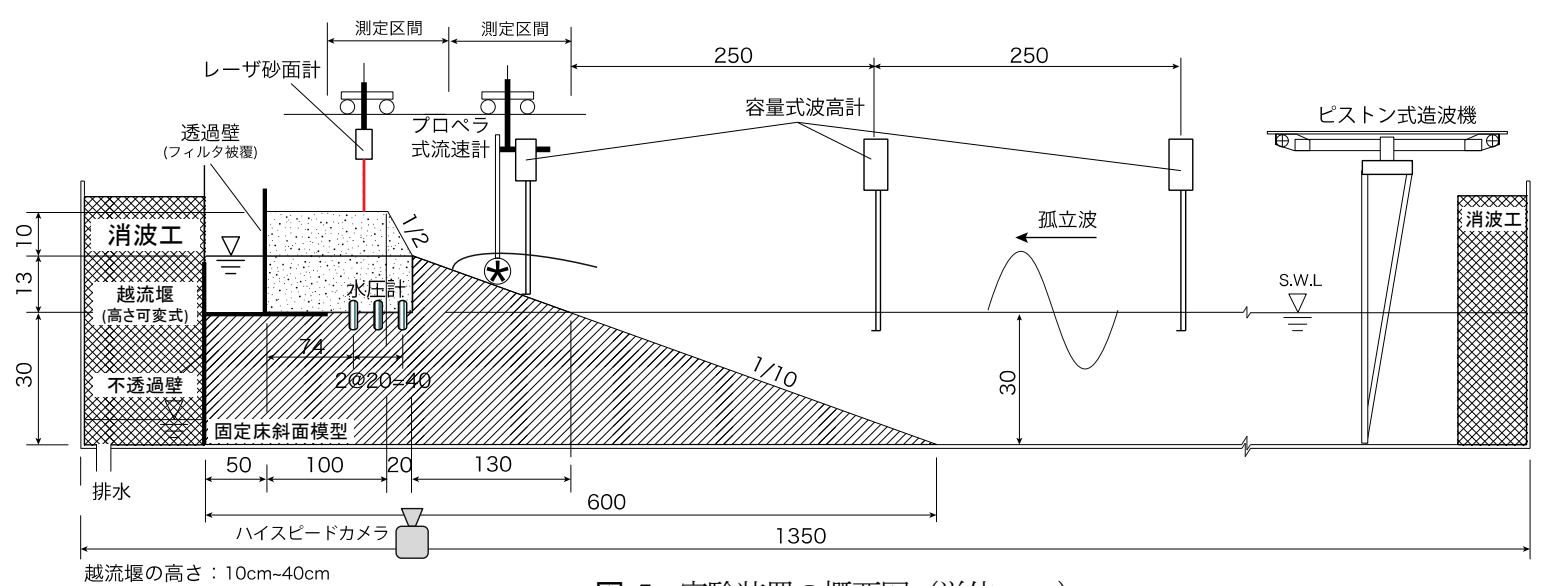

図-5＼cjkstart実験装置の概要図（単位 : cm）

ギー方程式により求めた宮武らのの方法を準用し，観測 された遡上波 $R$ に対応する遡上波先端流速を遡上流速 $u$ として算出した. 併せて, デジタルビデオカメラによる 水脈厚 $\eta$ を計測した.

\section{（2）後浜斜面に被災を発生させる遡上波の特性}

図-4は，沖波波高 $H_{o}$ と遡上高 $R$ との関係であり，図中 $の D_{1}$ と $D_{2}$ は後浜斜面の道路法肩高と道路法先高である.

被災相当波浪を作用させたときの $R_{2 \% /} D_{1}$ および $R_{110} D_{1}$ の 值は，それぞれ1.11，0.97となった．現地における後浜 斜面の被災は， $D_{1} \sim D_{2}$ の範囲で発生しており，道路面ま で波の遡上痕があったことから，道路法肩高 $D_{1}$ まで波が 遡上していたことを表している．以上の結果から， $R_{2 \%}$ （exp）が現地の遡上高を再現できたと想定される.

図中には参考として，既往の玉田ら》の式による計算 值（cal）も掲示しているが，実験值を過小評価してお り， $D_{2}$ を下回ることから, 被災時の遡上痕とも整合がと れていない．これは計算式が一様勾配の条件で行った実 験結果を基にしているためであり，本検討には適用でき ないことを確認した．また，遡上高に及ぼす周期の依存 性を調べるため，被災相当波浪の周期をべースに大小に 振った2種類の周期に対し，波高5パターンで行った. そ の結果，入射波の波高が同じでも周期の増大に伴い遡上 高が大きくなる傾向にあり, 被災相当波浪以下でも $D_{1}$ ま で波が到達する場合がある，以上のことから，後浜斜面 の被災が生じるリスクは，来襲する波の周期に依存して いることがいえる。

\section{（3）孤立波による後浜盛土斜面の破壊実験}

次に後浜盛土斜面の破壊メカニズムを解明するため, 孤立波による後浜盛士斜面の破壊実験を行った。実験は, 2次元造波水路内（長さ $23.5 \mathrm{~m}$, 幅 $0.5 \mathrm{~m}$, 深さ $1.0 \mathrm{~m}$ ） に代 表粒径 $0.28 \mathrm{~mm}$ の珪砂を用い道路盛土斜面を成形した

（図-5）。盛土は，製作過程や後浜から与える水位によ って，表一2のように地盤の性状を変化させた．Run1〜
表-2 後浜盛土の性状条件

\begin{tabular}{c|c|c|c}
\hline & $\begin{array}{c}\text { 相対密度 } \\
D_{r}(\%)\end{array}$ & $\begin{array}{c}\text { 飽和度 } \\
S_{r}(\%)\end{array}$ & $\begin{array}{c}\text { せん断強度 } \\
\tau(\mathrm{kPa})\end{array}$ \\
\hline Run1 & 43.0 (緩い) & 81.0 (不飽和) & 0.669 \\
Run2 & 52.0 (緩い) & 100.0 (飽 和) & 0.725 \\
Run3 & 67.0 (中密) & 83.0 (不飽和) & 1.81 \\
Run4 & 75.0 (中密) & 100.0 (飽 和) & 0.770 \\
Run5 & 88.0 (密) & 87.0 (不飽和) & 2.06 \\
Run6 & 84.0 (密) & 100.0 (飽 和) & 0.948 \\
\hline \hline
\end{tabular}

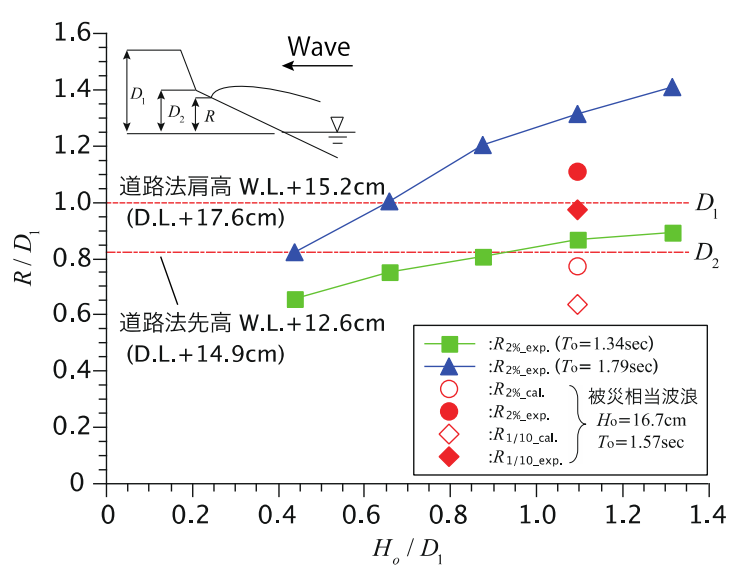

図-4 波の遡上高

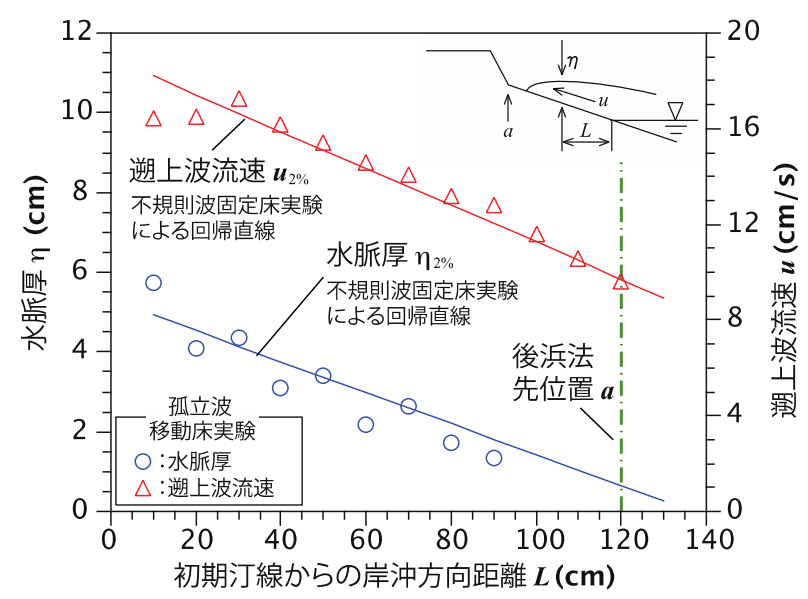

図-6 遡上流速および水脈厚 
Run6に対応した間隙比eはそれぞれ，0.74，0.70，0.66， 0.65，0.50，0.59である。なお，相似率はFroude相似率を 採用し, 後浜粒径は以下に示すKozeny-Donatの式を用い, 透水係数の相似則から規定した.

$$
k=\frac{C_{k}}{\mu} \frac{\lambda^{3}}{(1-\lambda)^{2}} D_{w}^{2}
$$

ここに， $C_{k}$. 砂粒子の形状による定数, $\mu$ : 水の粘性係数, $\lambda$ :砂粒子の空隙率， $D_{w}$ : 代表粒径である.

現地において, 後浜斜面の被災を発生させた遡上波は, 砕波に伴う乱れや先行波による戻り流れとの干渉など複 雑な水理現象を呈していると考えられる. 本実験では, 前述のように地盤性状による後浜盛土斜面の崩壊メカ二 ズムの解明を主眼としているため, 現象を単純化し，入 射波には孤立波を用いた。 入射させる孤立波は，前述し た不規則波固定実験 ${ }^{8)}$ において被災相当波浪を与え，現 地の遡上痕と同等となった $R_{2 \%}$ 遡上高に相当する水脈厚 $\eta_{2 \%}$ および遡上波流速 $u_{2 \%}$ を抽出して線形回帰で得た直線 に一致するよう検定し（図一），被災時の遡上波を再現 させた．この結果，孤立波の諸元は， $H=8.1 \mathrm{~cm}, T=11.0 \mathrm{~s}$ である.この孤立波を4分間隔で10波作用させ，1/10勾配 の前浜斜面上の波浪変形，遡上波変形およひ遡上流速， 地下水位, 縦断地形変化の計測をそれぞれ波高計, 八イ スピードカメラ, プロペラ流速計，水圧計，レーザー砂 面計により計測した.
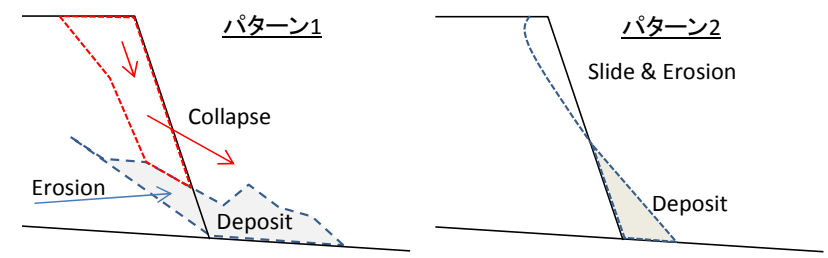

図-8 道路幅員の欠損パターン

\section{4. 地盤性状の違いによる後浜斜面の破壊特性}

\section{(1) 後浜斜面の破壊パターン}

図-7は後浜盛土性状による被害状況である，後浜盛土 斜面の破壊パターンは，飽和度に関わらず，図-8に示す ように，盛土斜面が緩い状態の場合（Run1,2），法先付 近の侵食が進行し，その後，これより上部にある法肩付 近が大きく崩壊するパターン 1 , 後浜盛土斜面が中密な 状態の場合（Run3,4）では，法肩付近の斜面の洗掘が先 行し, 法先付近にその土砂が堆積するパターン2に大き く分類される。後浜盛土斜面を更に密にした状態

（Run5,6）では基本的に中密な状態のパターン2に準じ て破壊が進行する。パターン2で破壊するRun3とほぼ同

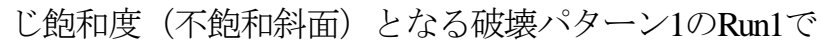
は，道路法肩部の侵食がRun3と比較して，より道路幅 員側に及び，道路の一部を欠損させるまでに至る。一方， Run3と同じ中密な状態の盛土を飽和にしたRun4は，同 じ飽和斜面およびせん断強度を有する中密状態のRun2
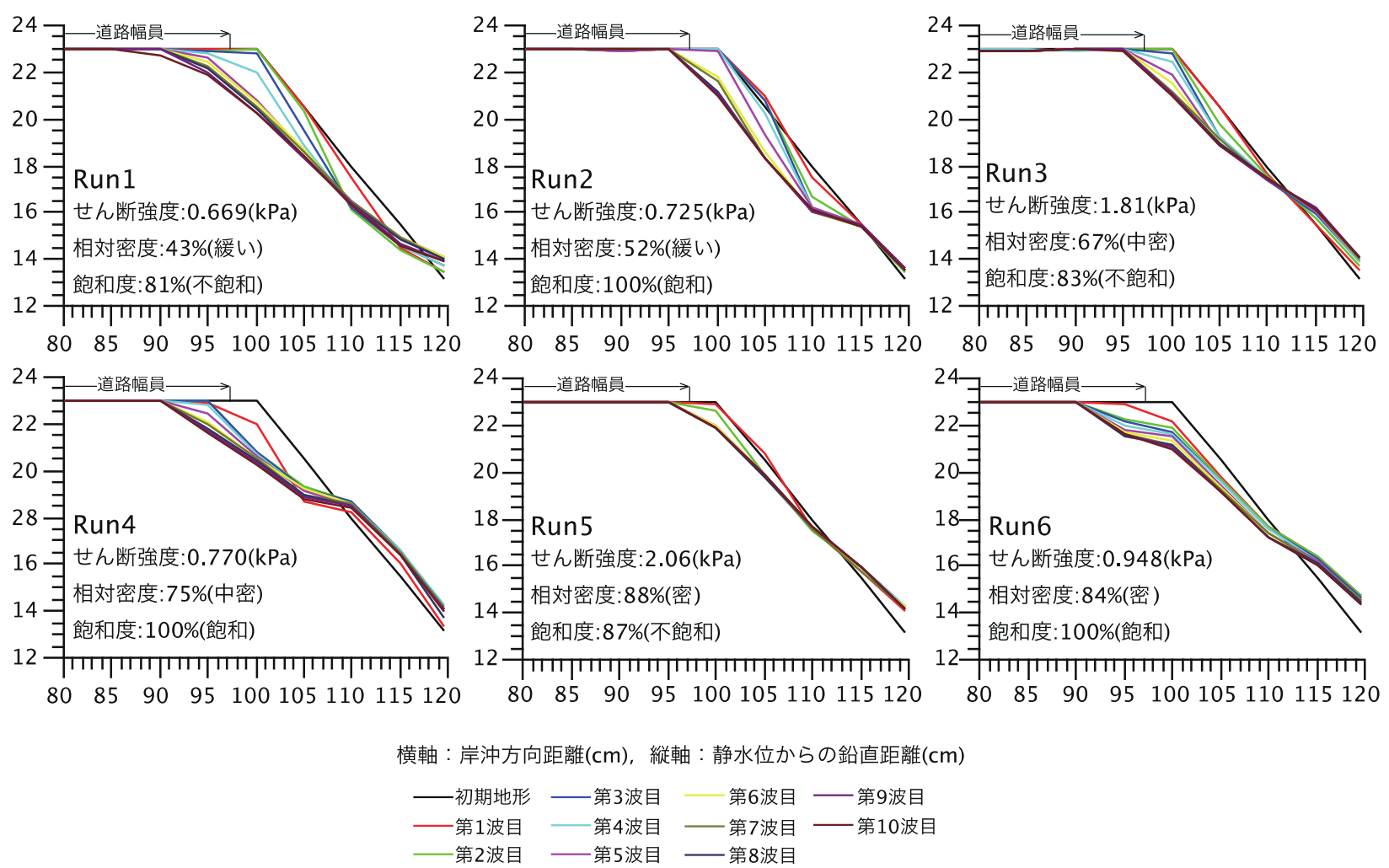

図-7＼cjkstart地盤性状の違いによる被害状況 

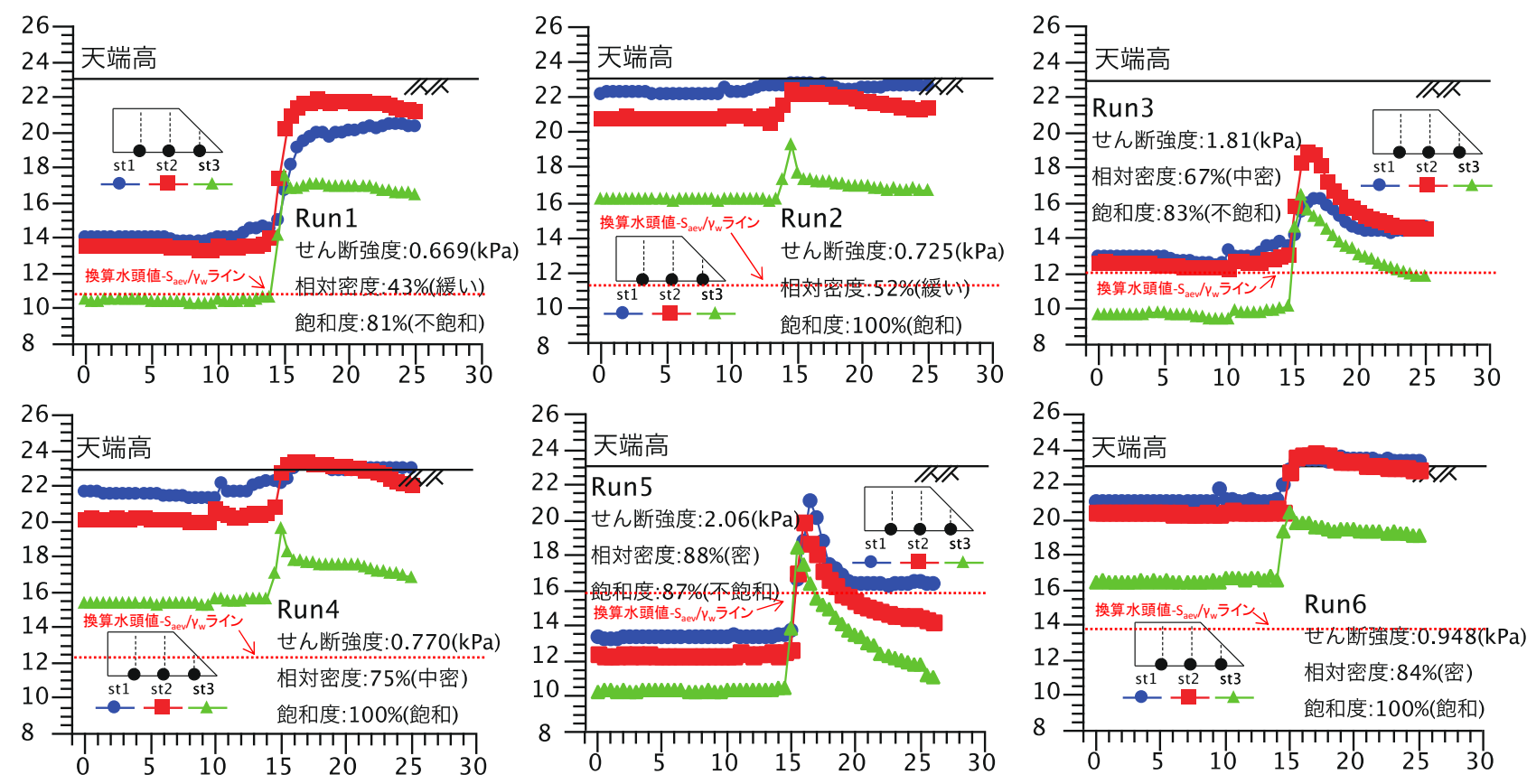

横軸 : 時間 $(\mathrm{s})$, 縦軸 : 静水位からの鉛直距離 $(\mathrm{cm})$

図-9 後浜盛土と地下水位の時系列変化

の破壊パターンとは明らかに異なっている. 後浜盛土斜 面の破壊は，Run1と同様に法肩部の侵食が進行し，道 路幅員の一部を欠損させる. この両ケースはそれぞれ, 相対密度の低下及び飽和度の増加に伴い，盛土自身のせ ん断強度が低下したことで，道路幅員の大規模な欠損を 発生させている. Run5では，Run3と同様の破壊形態と なるが，初期のせん断強度および相対密度が大きいため, 盛土自身の強度が大きく, 道路幅員の欠損が最も小さい 結果となった.

\section{(2) 地下水位の時系列変化}

図-9は，後浜盛土と地下水位の時系列変化であり，図

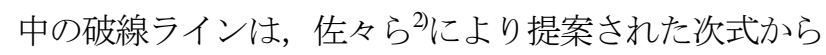
求まる，土中水分が保持される換算水頭值一 $\mathrm{s}_{\mathrm{ade}} / \gamma_{\mathrm{w}}$ を示 している.

$$
S_{a e v}=\frac{\psi}{e \cdot D_{10}} \gamma_{\mathrm{w}}
$$

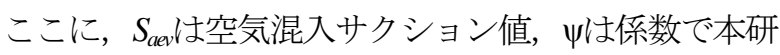
究では $20 \mathrm{~mm}^{2}$ を適用している. 全てのケースにおいて最 も沖側の地下水位が14〜15s付近で急激に上昇し，それ にやや遅れ岸側の地下水位が上昇している，側面から撮 影した動画解析から，地下水位が上昇する時間帯は，遡 上波が測定点に到達した時間とほぼ一致し，地下水位は 波の遡上に対して俊敏に応答する. 一方，地下水位が低 下寸る引き波時では，盛土性状や飽和度に応じ，低下速 度が大きく異なり，この違いが盛土斜面の崩壊に大きく 影響を与えていると考えられる.
Run1,3,5の結果から，地下水位は不飽和斜面の空隙が 大きくなると上昇量及ひ砂層内の貯留される浸透水量が 増加し, 相対密度の低下に伴う盛土自身のせん断強度の 低下を助長させ，道路法肩部の洗掘を加速させているも のと考えられる. 特に不飽和斜面のRun1においては, 高波によるサクション低下に伴うコラップス現象がみら れた。一方，Run2,4,6から，地下水位はほぼ天端高に達 し，より法肩部の洗掘を生じやすい環境下にあったと考 えられ，特に密な状態になる程，遡上波による変動水圧 の影響を受けやすくなり, 法肩の洗掘が進行するものと 考えられる.

\section{(3) 崩壊土砂量}

図-10は後浜盛土斜面の崩壊がほぼ収束する10波の孤 立波を作用させた後の相対密度と崩壊土砂量及びせん断 強度の関係である．飽和斜面の場合（Run2,4,6）では, 崩壊量の変化が小さい. 相対密度が増加しても土粒子間

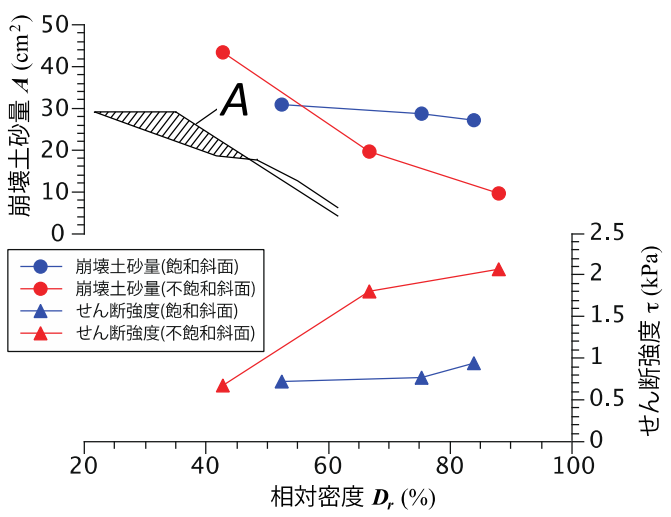

図-10 相対密度と崩壊土砂量およびせん断強度の関係 
のサクションが消失した状況にあり，せん断強度はほぼ 一定に推移しているためと考えられる。不飽和斜面の場 合（Run1,3,5）では，盛土が高密度化する程，せん断強 度が大きくなるだけでなく土粒子間のサクションも大き くなるため崩壊量が減少しているが，特に相対密度が低 下寸る程, 崩壊量は飽和斜面より大きくなる傾向となる.

\section{5. 結論}

オホーツク海沿岸域における海岸道路の後浜斜面の 被災箇所における調査結果および水理模型実験により得 られた結果は以下の通りである.

(1) オホーツク海沿岸域における後浜斜面において季節 変動による地盤性状変化が大きいことを確認した.

(2) 緩い不飽和斜面では高波によるサクション低下に伴 うコラップス現象，中～密な不飽和斜面では高波に よる洗掘が確認され, 相対密度及び飽和度の変化に 伴う海岸道路幅員の欠損パターンを明らかにし， 地盤性状変化を考慮した海岸道路の後浜斜面の高 波による破壊メカニズムを解明した。

（3）後浜斜面の崩壊量は, 相対密度と飽和度によって異 なることを明らかにした。

本研究で得られた知見は, 現場で起こりうるほぼ全て の物理状態（相対密度 : 30\%～90\%程度）を網羅してい ることから, 様々な地盤性状の後浜斜面の高波リスク評 価に資するものと考えられる.

\section{6. 今後の課題}

今後は，被害のあつた後浜斜面の事例を蓄積させ，
様々な粒径での破壊現象を追加検討するとともに，被災 時のより詳しい現地データ取得し, 実験結果の信頼性を 高めていく必要がある.

謝辞 : 本研究を進めるにあたり，函館工業高等専門学校 の荒木京祐氏の協力を得た. ここに記し謝意を表します.

\section{参考文献}

1) 猿渡亜由未, 渡部靖憲: 日本海上の爆弾低気圧に起因 する高波の発達機構, 海岸工学論文集 B2（海岸工 学) , Vol.71, No.2, pp.537-542, 2015.

2) 佐々真志, 渡部要一: 砂質干潟の土砂環境場における サクション動態とその果たす役割, 海岸工学論文集, 第 52 巻, pp.981-985, 2005.

3) 佐々真志, 渡部要一, 石井嘉一: 干潟と砂浜の保水動 態機構と許容地下水位の解明, 海岸工学論文集, 第 54 巻, pp.1151-1155, 2007.

4) Sassa, S., and Y.watabe: Role of suction dynamics in evolution of intertidal sandy flats: Field evidence, experiments, and theoretical model, Journal of Geophysical Research., Vol.112, F01003, 2007.

5) Sassa, S., Yang, S., Watabe, Y., Kajihara, N., and Y,Tanaka: Role of suction in sandy beach habitats and the distributions of three amphipod and isopod species, Journal of Sea Research., Vol.85, pp.336-342, 2014.

6) 宮武誠, 藤間聡: 波打ち帯の浸食・堆積過程に及ぼす 前浜地下水の流動特性, 土木学会論文集, No.754, pp.51-61, 2004

7) 玉田崇, 間瀬肇, 安田誠宏：複合断面に対する波の不 規則性を考慮した打ち上げ高算定法に関する研究, 土木学会論文集 B2（海岸工学）, Vol.65, No.1, pp.936940, 2009.

8) 本間大輔, 山本泰司, 宮武誠, 木村克俊: 高波による 海岸道路の盛土被害の発生条件と対策の検討, 土木学 会論文集 B3（海洋開発）, Vol.71, No.2, (40), 2015.

(2016.3.16 受付)

\title{
AN EXPERIMENT TO ELUCIDATE THE MECHANISMS BEHIND HIGH-WAVE-RELATED FAILURE OF BACKSHORE SLOPES ON COASTAL ROADS IN CONSIDERATION OF CHANGES IN GROUND PROPERTIES
}

\author{
Daisuke HONMA, Makoto MIYATAKE, Shinji SASSA, Katsutoshi KIMURA, \\ Hajime SHIROZU and Tsubasa EBIKO
}

In this study, on-site surveys based on reports of damage to backshore slopes on coastal roads along the Sea of Okhotsk in Hokkaido were conducted, and an embankment fracture experiment with model high waves was performed in consideration of the survey results. In the experiment, ground with varying relative density and vane shear strength was used to simulate various states of soil suction dynamics. The results highlighted the collapse phenomenon that occurs when soil suction is reduced by high waves on a partially saturated and loosened slope, and scouring caused by high waves was observed on a partially saturated slope with medium-to-high density. The patterns of coastal road damage that follow changes in the relative density and degree of saturation seen in the field soils were clarified, and the mechanism behind high-wave-related failure on coastal roads was elucidated in relation to changes in soil properties. The volume of backshore slope collapse was also found to depend on the relative density and degree of saturation of the slope's soil. 